\title{
Contact Toxicity of Certain Conventional Insecticides to European Honeybee, Apis mellifera Linnaeus
}

\author{
V. Ratnakar ${ }^{1 *}$, S.R. Koteswara Rao ${ }^{3}$, D. Sridevi ${ }^{1}$ and B. Vidyasagar $^{2}$ \\ ${ }^{1}$ Department of Entomology, ${ }^{2}$ Department of Plant Pathology, College of Agriculture, Prof. \\ Jayashankar Telangana State Agricultural University, Rajendranagar, Hyderabad- 500 030, India \\ ${ }^{3}$ Department of Entomology, S. V. Agricultural College, Acharya N.G. Ranga Agricultural \\ University, Tirupati-517 502, India \\ *Corresponding author
}

\section{A B S T R A C T}

\begin{tabular}{l} 
Ke y w or d s \\
Honeybee, \\
Apis mellifera, \\
Insecticides, \\
Toxicity. \\
\hline Article Info \\
\hline $\begin{array}{l}\text { Accepted: } \\
\text { 26 June } 2017 \\
\text { Available Online: } \\
\text { 10 August } 2017\end{array}$ \\
\hline
\end{tabular}

\section{Introduction}

Honey bees have a key role in agriculture and environmental preservation. Beekeeping is a fundamental agricultural activity, not only for providing hive products as honey, wax, pollen, venom, royal jelly etc., but also for assuring pollination of a large number of crops. The major part of cultivated plants, in fact, needs insect pollination in order to be fecundated. Moreover, honey bees together with other pollinators provide the pollination of the spontaneous and wild vegetation, thus playing a major role in landscape and natural resource preservation and domestic honey bees strongly contributed to that (Klein et al., 2007). Use of pesticides for pest management on one hand and the role of honeybees for crop pollination on the other, have become essential components of modern agriculture. Unfortunately, these two practices are not always compatible, as honeybees are susceptible to many of commonly used pesticides (Sundararaju, 2003 and Brittain et al., 2010). Conservation of honeybees for crop pollination is vital to agricultural production (Kremen et al., 2002). In India, $90 \%$ of the pollination of crops grown across 50 million hectares was done by bees. Although poorly studied, a harmonious compromise between pest management and honeybee pollination of crops in India is clearly important. Widespread use of pesticides in modern agriculture throughout 
the world has become necessary for protection of crops against insect pests and diseases to avoid crop losses and to meet the food requirement of increasing population, but the injudicious use of pesticides has resulted in contamination of not only the agro ecosystem and agricultural produce, but also of nectar and pollen causing heavy losses to honeybees and other pollinators. Knowledge of relative safety of insecticides during flowering is essential to obtain maximum benefits from bee pollination. With this prelude, an experiment was conducted to evaluate the safety of certain insecticides to European honeybee, Apis mellifera L.

\section{Materials and Methods}

Conventional insecticides viz., acephate, chlorpyriphos, dichlorvos, dimethoate, profenophos, triazophos, cypermethrin and neem oil were evaluated at recommended doses for their toxicity to European honeybee A.mellifera in the laboratory of Department of Entomology, College of Agriculture, Rajendranagar, Hyderabad during August 2014 to May 2015. Forager honeybees were collected at the entrance of the hive with the cone type muslin hand net (30 cm diameter), put in plastic jars and were immobilized by keeping them in deep freezers / refrigerator for about 5 minutes. (Sharma and Abrol, 2005). They were allowed to recover from cold treatment before exposure to insecticides.

The test insecticides were evaluated for their toxicity by dry film method. In this method, recommended doses of insecticides formulation were diluted in one litre of distilled water to make the spray solutions. One $\mathrm{ml}$ each of the respective test insecticide was transferred to a clean dry rearing jar of size $10 \times 7 \mathrm{~cm}$ diameter. The jar was gently rotated and left for drying so that a thin dry film of the chemical was formed inside the jar. Ten forage adult bees were released into the each jar at different intervals i.e. 0, 12 and 24 hours of after dry film formation and within each interval, data on mortality of the bees was recorded at 2, 4, 6, 12, 24 and 48 hours. These intervals were considered since bees could be exposed to insecticides in the field any time after their spray and it is necessary to understand the residual toxicity of these insecticides on the bees. A cotton pad soaked in sugar solution $(20 \%)$ was provided inside the jar and it was covered using muslin cloth. Each treatment was replicated thrice and a jar with a dry film of water served as control. The data obtained was analyzed statistically (Sokal and Rholf, 1981) using WINDOWSTAT package. Abbott's (1925) formula was used to arrive at the corrected natural mortality. Bees were recorded as dead when gentle pressure upon the abdomen did not bring any twitching movement or positive response over a half an hour inspection period.

\section{Results and Discussion}

Effect of certain conventional insecticides at recommended dose on mortality of honeybees exposed 0 hours after dry film formation (Table 1)

After 2 hours, among the treatments, highest mortality was recorded by acephate $(100 \%)$ which was on par with dichlorvos $(98.61 \%)$ and cypermethrin (95.22\%). Dimethoate, cypermethrin. triazophos, profenophos and chlorpyriphos caused 46.62 to 86.95 per cent mortality Lowest mortality was recorded by neem oil (9.99\%). 100 per cent mortality was recorded by acephate, dichlorvos and cypermethrin after 4 hours. Dimethoate, triazophos and profenophos registered 49.97 to 69.96 per cent mortality, Neem oil was the least toxic causing 9.99 per cent mortality. After 6 hours, cent per cent mortality was observed in acephate, dichlorvos, 
cypermethrin and dimethoate treated jars. Triazophos, profenophos and chlorpyriphos recorded 67.22 to 80.68 per cent moratlity, while neem oil caused 10.02 per cent mortality which were significantly different from each other and also from other treatments.

100 per cent mortality was registered in acephate, dichlorvos, cypermethrin and dimethoate treatments after 12 hours. Triazophos, profenophos and chlorpyriphos caused between 81.78 and 97.02 per cent mortality. Neem oil was found to register significantly lowest $(11.10 \%)$ mortality. At the end of 24 hours, 100 per cent mortality was recorded by acephate, dichlorvos, cypermethrin, dimethoate and triazophos while profenophos and chlorpyriphos caused 98.49 and 97.02 per cent, respectively which were on par with above five insecticides. Only 11.10 per cent mortality was seen in neem oil treatment after 24 hours. After 48 hours, cent per cent mortality of honeybees, Apis mellifera was recorded by all insecticides except neem oil.

Acephate recorded cent per cent mortality within 2 hours while dichlorvos and cypermethrin exhibited cent per cent mortality after 4 hours. Dimethoate and triazophos recorded cent per cent mortality after 6 and 24 hours respectively. By 48 hours all the treatments except neem oil caused cent per cent mortality.

Effect of certain conventional insecticides at recommended dose on mortality of honeybees exposed after 12 hours of dry film formation (Table.1)

Dimethoate and cypermethrin caused highest mortality of 79.96 per cent after 2 hours. Profenophos, triazophos, dichlorvos and chlorpyriphos registered 9.99 to 63.37 per cent mortality. Neem oil was found to be the safest causing 1.40 per cent mortality. After 4 hours, 79.96 per cent mortality was exhibited by acephate, cypermethrin and dimethoate. Triazophos, profenophos, caused mortality of 63.37 per cent, while dichlorvos and neem oil caused lesser mortality of 9.99 and 1.40 per cent. Maximum mortality of 89.97 per cent was observed in acephate, cypermethrin and dimethoate after 6 hours. Triazophos profenophos, chlorpyriphos recorded 63.37 to 76.78 per cent mortality. Among all treatments, least mortality (9.99 and 1.40 per cent) was caused by dichlorvos and neem oil, respectively.

At the end of 12 hours, cent per cent mortality was recorded by acephate, cypermethrin and dimethoate. Triazophos, chlorpyriphos, dichlorvos and profenophos registered mortality in the range of 59.29-77.74 per cent. Neem oil recorded lowest mortality of 1.55 per cent. Acephate, cypermethrin and dimethoate caused cent per cent mortality after 24 hours which were on par with dichlorvos and chlorpyriphos. Neem oil recorded only 1.55 per cent mortality. After 48 hours, cent per cent mortality was exhibited by acephate, cypermethrin, dimethoate, triazophos, profenophos and chlorpyriphos, while dichlorvos recorded 98.49 per cent mortality and was on par with above treatments. Neem oil recorded least mortality of 11.10 per cent. Acephate, dimethoate and cypermethrin recorded cent per cent mortality after 12 hours.

Triazophos and chlorpyriphos showed an increasing trend of mortality and attained cent per cent mortality after 48 hours. Dichlorvos recorded 9.99, 59.29 and 98.49 per cent mortality of honeybees after 6, 12 and 48 hours. Neem oil recorded lowest mortality among all causing 1.40 per cent after 2 hours to 11.10 per cent after 48 hours. 
Table.1 Effect of certain conventional insecticides at recommended dose on mortality of European honeybee, Apis mellifera L.

\begin{tabular}{|c|c|c|c|c|c|c|c|c|c|c|c|c|c|c|c|c|c|c|c|}
\hline \multirow{3}{*}{ Treatments } & \multirow{3}{*}{$\begin{array}{c}\text { Dose } \\
(\mathrm{ml} \text { or } \\
\mathrm{g} / \mathrm{l})\end{array}$} & \multicolumn{18}{|c|}{ Per cent mortality of honey bees exposed Immediately,12 and 24 hours after dry film formation } \\
\hline & & \multicolumn{6}{|c|}{ Immediately after dry film formation } & \multicolumn{6}{|c|}{12 hours after dry film formation } & \multicolumn{6}{|c|}{24 hours after dry film formation } \\
\hline & & $2 \mathrm{hr}$ & $4 \mathrm{hr}$ & $6 \mathrm{hr}$ & $12 \mathrm{hr}$ & $24 \mathrm{hr}$ & $48 \mathrm{hr}$ & $2 \mathrm{hr}$ & $4 \mathrm{hr}$ & $6 \mathrm{hr}$ & $12 \mathrm{hr}$ & $24 \mathrm{hr}$ & $48 \mathrm{hr}$ & $2 \mathrm{hr}$ & $4 \mathrm{hr}$ & $6 \mathrm{hr}$ & $12 \mathrm{hr}$ & $24 \mathrm{hr}$ & $48 \mathrm{hr}$ \\
\hline Acephate & $1.5 \mathrm{~g}$ & $\begin{array}{c}100 \\
(90.00)\end{array}$ & $\begin{array}{l}100 \\
(90)\end{array}$ & $\begin{array}{l}100 \\
(90)\end{array}$ & $\begin{array}{l}100 \\
(90)\end{array}$ & $\begin{array}{c}100 \\
(90.00)\end{array}$ & $\begin{array}{l}100 \\
(90)\end{array}$ & $\begin{array}{c}69.96 \\
(56.77)\end{array}$ & $\begin{array}{c}79.96 \\
(63.41)\end{array}$ & $\begin{array}{c}89.97 \\
(71.54)\end{array}$ & $\begin{array}{l}100 \\
(90)\end{array}$ & $\begin{array}{l}100 \\
(90)\end{array}$ & $\begin{array}{l}100 \\
(90)\end{array}$ & $\begin{array}{c}50 \\
(45)\end{array}$ & $\begin{array}{c}86.99 \\
(68.85)\end{array}$ & $\begin{array}{l}100 \\
(90)\end{array}$ & $\begin{array}{l}100 \\
(90)\end{array}$ & $\begin{array}{l}100 \\
(90)\end{array}$ & $\begin{array}{l}100 \\
(90)\end{array}$ \\
\hline Chlorpyriphos & $2.5 \mathrm{ml}$ & $\begin{array}{c}46.62 \\
(43.06)\end{array}$ & $\begin{array}{c}49.97 \\
(44.98)\end{array}$ & $\begin{array}{c}67.22 \\
(55.07)\end{array}$ & $\begin{array}{c}81.78 \\
(64.74)\end{array}$ & $\begin{array}{c}97.02 \\
(80.05)\end{array}$ & $\begin{array}{l}100 \\
(90)\end{array}$ & $\begin{array}{c}33.23 \\
(35.20)\end{array}$ & $\begin{array}{c}33.23 \\
(35.20)\end{array}$ & $\begin{array}{c}63.37 \\
(52.75)\end{array}$ & $\begin{array}{c}77.74 \\
(61.85)\end{array}$ & $\begin{array}{c}98.49 \\
(82.94)\end{array}$ & $\begin{array}{l}100 \\
(90)\end{array}$ & $\begin{array}{c}33.26 \\
(35.22)\end{array}$ & $\begin{array}{c}46.65 \\
(43.08)\end{array}$ & $\begin{array}{c}56.69 \\
(48.84)\end{array}$ & $\begin{array}{c}63.00 \\
(52.54)\end{array}$ & $\begin{array}{c}98.48 \\
(82.93)\end{array}$ & $\begin{array}{l}100 \\
(90)\end{array}$ \\
\hline Dichlorvos & $1 \mathrm{ml}$ & $\begin{array}{c}98.61 \\
(83.22)\end{array}$ & $\begin{array}{l}100 \\
(90)\end{array}$ & $\begin{array}{l}100 \\
(90)\end{array}$ & $\begin{array}{l}100 \\
(90)\end{array}$ & $\begin{array}{l}100 \\
(90)\end{array}$ & $\begin{array}{l}100 \\
(90)\end{array}$ & $\begin{array}{c}9.99 \\
(18.43)\end{array}$ & $\begin{array}{c}9.99 \\
(18.43)\end{array}$ & $\begin{array}{c}9.99 \\
(18.43)\end{array}$ & $\begin{array}{c}59.29 \\
(50.35)\end{array}$ & $\begin{array}{c}98.49 \\
(82.94)\end{array}$ & $\begin{array}{c}98.49 \\
(82.94)\end{array}$ & $\begin{array}{c}0.03 \\
(0.99)\end{array}$ & $\begin{array}{c}0.03 \\
(0.99)\end{array}$ & $\begin{array}{c}20.02 \\
(26.58)\end{array}$ & $\begin{array}{c}36.94 \\
(37.43)\end{array}$ & $\begin{array}{c}81.78 \\
(64.73)\end{array}$ & $\begin{array}{c}97.01 \\
(80.05)\end{array}$ \\
\hline Dimethoate & $2 \mathrm{ml}$ & $\begin{array}{c}86.95 \\
(68.83)\end{array}$ & $\begin{array}{c}95.22 \\
(77.38)\end{array}$ & $\begin{array}{l}100 \\
(90)\end{array}$ & $\begin{array}{l}100 \\
(90)\end{array}$ & $\begin{array}{l}100 \\
(90)\end{array}$ & $\begin{array}{l}100 \\
(90)\end{array}$ & $\begin{array}{c}79.96 \\
(63.41)\end{array}$ & $\begin{array}{c}79.96 \\
(63.41)\end{array}$ & $\begin{array}{c}89.97 \\
(71.54)\end{array}$ & $\begin{array}{l}100 \\
(90)\end{array}$ & $\begin{array}{l}100 \\
(90)\end{array}$ & $\begin{array}{l}100 \\
(90)\end{array}$ & $\begin{array}{c}83.64 \\
(66.14)\end{array}$ & $\begin{array}{c}86.99 \\
(68.85)\end{array}$ & $\begin{array}{l}100 \\
(90)\end{array}$ & $\begin{array}{l}100 \\
(90)\end{array}$ & $\begin{array}{l}100 \\
(90)\end{array}$ & $\begin{array}{l}100 \\
(90)\end{array}$ \\
\hline Profenophos & $2 \mathrm{ml}$ & $\begin{array}{c}59.96 \\
(50.75)\end{array}$ & $\begin{array}{c}66.71 \\
(54.76)\end{array}$ & $\begin{array}{c}80.68 \\
(63.93)\end{array}$ & $\begin{array}{c}85.50 \\
(67.62)\end{array}$ & $\begin{array}{c}98.49 \\
(82.94)\end{array}$ & $\begin{array}{l}100 \\
(90)\end{array}$ & $\begin{array}{c}63.37 \\
(52.75)\end{array}$ & $\begin{array}{c}63.37 \\
(52.75)\end{array}$ & $\begin{array}{c}69.96 \\
(56.77)\end{array}$ & $\begin{array}{c}70.48 \\
(57.09)\end{array}$ & $\begin{array}{c}81.78 \\
(64.74)\end{array}$ & $\begin{array}{l}100 \\
(90)\end{array}$ & $\begin{array}{c}53.35 \\
(46.92)\end{array}$ & $\begin{array}{c}56.69 \\
(48.84)\end{array}$ & $\begin{array}{c}66.74 \\
(54.78)\end{array}$ & $\begin{array}{c}70.49 \\
(57.09)\end{array}$ & $\begin{array}{c}74.19 \\
(59.47)\end{array}$ & $\begin{array}{l}100 \\
(90)\end{array}$ \\
\hline Triazophos & $2.5 \mathrm{ml}$ & $\begin{array}{c}69.96 \\
(56.77)\end{array}$ & $\begin{array}{c}69.96 \\
(56.77)\end{array}$ & $\begin{array}{c}83.64 \\
(66.14)\end{array}$ & $\begin{array}{c}97.02 \\
(80.05)\end{array}$ & $\begin{array}{l}100 \\
(90)\end{array}$ & $\begin{array}{l}100 \\
(90)\end{array}$ & $\begin{array}{c}63.37 \\
(52.75)\end{array}$ & $\begin{array}{c}63.37 \\
(52.75)\end{array}$ & $\begin{array}{c}76.78 \\
(61.20)\end{array}$ & $\begin{array}{c}77.74 \\
(61.85)\end{array}$ & $\begin{array}{c}85.50 \\
(67.62)\end{array}$ & $\begin{array}{l}100 \\
(90\end{array}$ & $\begin{array}{c}53.35 \\
(46.92)\end{array}$ & $\begin{array}{c}60 \\
(50.77)\end{array}$ & $\begin{array}{c}73.47 \\
(59.00)\end{array}$ & $\begin{array}{c}81.78 \\
(64.74)\end{array}$ & $\begin{array}{c}98.48 \\
(82.93)\end{array}$ & $\begin{array}{l}100 \\
(90)\end{array}$ \\
\hline Cypermethrin & $0.4 \mathrm{ml}$ & $\begin{array}{c}95.22 \\
(77.38)\end{array}$ & $\begin{array}{l}100 \\
(90)\end{array}$ & $\begin{array}{l}100 \\
(90)\end{array}$ & $\begin{array}{l}100 \\
(90)\end{array}$ & $\begin{array}{l}100 \\
(90)\end{array}$ & $\begin{array}{l}100 \\
(90)\end{array}$ & $\begin{array}{c}79.96 \\
(63.41)\end{array}$ & $\begin{array}{c}79.96 \\
(63.41)\end{array}$ & $\begin{array}{c}89.97 \\
(71.54)\end{array}$ & $\begin{array}{l}100 \\
(90)\end{array}$ & $\begin{array}{l}100 \\
(90)\end{array}$ & $\begin{array}{l}100 \\
(90)\end{array}$ & $\begin{array}{c}69.99 \\
(56.79)\end{array}$ & $\begin{array}{c}76.81 \\
(61.22)\end{array}$ & $\begin{array}{c}86.99 \\
(68.85)\end{array}$ & $\begin{array}{c}98.49 \\
(82.94)\end{array}$ & $\begin{array}{l}100 \\
(90)\end{array}$ & $\begin{array}{l}100 \\
(90)\end{array}$ \\
\hline Neem Oil & $5 \mathrm{ml}$ & $\begin{array}{c}9.99 \\
(18.43)\end{array}$ & $\begin{array}{c}9.99 \\
(18.43)\end{array}$ & $\begin{array}{c}10.02 \\
(18.46)\end{array}$ & $\begin{array}{c}11.10 \\
(19.46)\end{array}$ & $\begin{array}{c}11.10 \\
(19.46)\end{array}$ & $\begin{array}{r}11.10 \\
(19.46\end{array}$ & $\begin{array}{c}1.40 \\
(6.80)\end{array}$ & $\begin{array}{c}1.40 \\
(6.80)\end{array}$ & $\begin{array}{c}1.40 \\
(6.80)\end{array}$ & $\begin{array}{c}1.54 \\
(7.14)\end{array}$ & $\begin{array}{c}1.55 \\
(7.15)\end{array}$ & $\begin{array}{c}11.10 \\
(19.46)\end{array}$ & $\begin{array}{c}0.03 \\
(0.99)\end{array}$ & $\begin{array}{c}0.03 \\
(0.99)\end{array}$ & $\begin{array}{c}0.03 \\
(0.99)\end{array}$ & $\begin{array}{c}0.03 \\
(0.99)\end{array}$ & $\begin{array}{c}0.03 \\
(0.99)\end{array}$ & $\begin{array}{c}1.54 \\
(7.14)\end{array}$ \\
\hline S.Em \pm & & 3.148 & 2.48 & 2.614 & 3.526 & 3.897 & 0 & 2.39 & 2.39 & 2.31 & 2.45 & 4.06 & 2.19 & 1.53 & 1.83 & 1.58 & 2.78 & 3.37 & 3.88 \\
\hline C.D (0.05) & & 9.518 & 7.5 & 7.904 & 10.662 & 11.783 & 0 & 7.23 & 7.23 & 6.98 & 7.43 & 12.27 & 6.64 & 4.63 & 5.55 & 4.77 & 8.42 & 10.21 & 11.74 \\
\hline
\end{tabular}

Figures in parentheses are angular transformed values 
Effect of certain conventional insecticides at recommended dose on mortality of honeybees exposed after 24 hours of dry film formation (Table.1)

Mortality of honeybees was highest in dimethoate $(83.64 \%)$ and cypermethrin $(69.99 \%)$ after 2 hours. In the rest of the treatments, it ranged between $33.26-53.35$ per cent. Among all treatments, dichlorvos and neem oil did not record any mortality. After 4 hours, acephate and dimethoate registered highest mortality of 86.99 per cent. Cypermethrin, chlorpyriphos, triazophos and profenophos exhibited 46.65-76.81 per cent mortality and were on par with each other. Dichlorvos and neem oil recorded nil mortality even after four hours of treatment. Cent per cent mortality was recorded by acephate, and dimethoate after 6 hours. Cypermethrin, triazophos, profenophos, chlorpyriphos and dichlorvos caused 86.99, $73.47,66.74,56.69$ and 20.02 per cent mortality, respectively and they significantly differed from each other. However, neem oil did not record any mortality.

At the end of 12 hours, 100 per cent mortality was observed in acephate and dimethoate treatments. The other treatments caused mortality ranging between 36.94 and 98.49 per cent. Neem oil was safer even after 12 hours recording nil mortality. After 24 hours, cent per cent mortality was recorded by acephate, cypermethrin and dimethoate. Mortality in the other treatments ranged between 74.19 to 98.48 per cent. Neem oil did not record any mortality even after 24 hours of exposure to the treatment. After 48 hours, cent per cent mortality was recorded in all treatments except neem oil which recorded only 1.55 per cent mortality.

Among all treatments, dimethoate reached cent per cent mortality after 6 hours. Acephate recorded cent per cent mortality after 6 hours, while cypermethrin caused cent per cent mortality after 24 hours. Both dichlorvos and neem oil did not record any mortality till 4 hours but subsequently dichlorvos at 48 hours caused its maximum mortality of 97.01 per cent at 48 hours. Neem oil caused no mortality till 24 hours and after 48 hours reached 1.55 per cent mortality.

Among organophosphates i.e., acephate, dimethoate, triazophos, profenophos, chlorpyriphos and dichlorvos were tested in the present investigation on $A$. mellifera. Majority of insecticides were moderately too highly toxic (46.62 to cent per cent mortality) to honeybees after 2 hours of exposure. Our results are in conformity with those of Sinha et al., (1997) who reported that majority of organophosphates were highly toxic to honeybees. When honeybees were exposed immediately to treated jars acephate exhibited highest toxicity after two hours. This is in concurrence with the findings of Hasansab et al., (2013) who reported similar findings. Dimethoate exhibited cent per cent mortality of A. mellifera within six hours of exposure to insecticides, which was also reported by Attri and Sharma (1969) who observed that dimethoate was highly toxic to A. cerana indica causing 100 per cent mortality within 72 hours. Findings of Reddy and Reddy (2006), Kumar (2007) and Gupta et al., (2007) are also in support of the present findings. Cent percent mortality was recorded in cypermethrin, after four hours when bees were released immediately after dry film formation. Results obtained in present study are in conformity with the findings of Wael and Laere (1989), Abrol (1997), Sharma and Abrol (2005), Muranjan et al., (2006) and Reddy and Reddy (2006) who reported that cypermethrin was highly toxic to honeybees.

Neem oil recorded least mortality after 48 hours of treatment. Thus it was found to be safest to the forager bees. The reason for the 
safety of azadirachtin to honeybee could be its low contact toxicity. Neem was reported to be safe to honeybees by Rembold and Czoppelt (1981), Schmutterer and Holst (1987), Abrol and Androtra (1997), Ladurner et al., (2005), Gour and Pareek (2005) and Akca et al., (2009). The order of safety was found to be neem oil > chlorpyriphos > profenophos > triazophos $>$ dichlorvos $>$ dimethoate $>$ cypermethrin $>$ acephate. The present study helped to understand the extent of safety of different insecticides to honey bees. Though insecticides are indispensable for crop protection, timing the sprays especially in the flowering stage of the crop helps avoid intervention with the natural activity of forager bees.

\section{References}

Abbott, W.S., 1925. A method of computing the effectiveness of insecticides. Journal of Economic Entomology. 18:265-267.

Abrol, D.P., 1997. Bees and beekeeping in India. Kalyani Publishers, Ludhiana, India.450pp.

Abrol, D.P., and Andotra, R.S. 1997. Contact toxicity of some pesticides to honey bee Apis mellifera Pest Management and Economic Zoology. 5(1): 47-51.

Akca, I., Tuncer, C., Guler, A and Saruhan, I. 2009. Residual toxicity of 8 different insecticides on honeybee (Apis mellifera Hymenoptera: Apidae). Journal of Animal and Veterinary Advances 8(3): 436-445.

Apidologie. 36(5): 449-460

Attri, B.S., and Sharma, P.L. 1969. Toxicity of some new insecticides to the Indian honeybee,'Apis mellifera L. Pesticides. 3(6): 27-29.

Brittain, C., Bommarco, B., Vighi, M., Barmaz, S., Settele, J and Potts, S.G. 2010. The impact of an insecticide on insect flower visitation and pollination in an agricultural landscape. Agricultural and Forest Entomology 12: 259-266.

Gour, I.S., and Pareek, B.L. 2005. Relative toxicity of some insecticides to coccinellid Coccinella septempunctata Linn. And Indian honey bee, Apis cerana indica. Indian Journal Agricutural Research. 39(4): 299-302.

Gupta, A.K., Virendra, K and Naresh K. 2007. Mortality of Indian honeybee, Apis cerena indica due to impact of some agricultural pesticides. Journal of ExperimentalZoology, India. 10(2): 391-393.

Hasansab, N., Yadav, G.S., Kaushik, H. D and Sharma, H.D. 2013. Toxicity of new molecules of insecticides against honeybee, Apis mellifera L. Trends in Biosciences 6 (4): 445-447.

Klein, A.M., Vaissière, B.E., Cane J.H., Steffan-D. I., Cunningham S.A., Kremen, C and Tscharntke, T., 2007. Importance of pollinators in changing landscapes for world crops.doi:10.1098/rspb.2006.3721.

Kremen, C., Williams, N.M and Tharp, R.W. 2002. Crop pollination from native bees at risk from agricultural diversification. Proceedings of the National Academy of Sciences USA.99 (26): 16812-16816

Kumar, S., 2007. Evaluation of certain agricultural pesticides and artificial diets on growthand development and biochemical activities in Italian honeybee Apis mellifera Ph.D Thesis. C.C.S University, Meerut

Ladurner, E., Bosch, J., Kemp, W.P and Maini, S. 2005. Assessing delayed and acute toxicity of five formulated fungicides to Osmia lignaria and Apis mellifera.

Muranjan, P.N., Gandhale, D.N., Chaudhari, C.S., Patil, B.D., Pokharkar, D.S and Naik, R.L. 2006. Toxicity of ready- 
mix formulations of pyrethroids and admixed insecticides on forager honey bee, Apis cerana indica F. Annals of Plant Protection Sciences. 14(1): 90-93.

Reddy, E.V., and Reddy, Ch. C 2006. Oral and dermal toxicity of some insecticides to Indian honey bee, Apis cerana F. Journal of Entomological Research 30 (1): 47-49.

Rembold, H., and Czoppelt, C. 1981. Evaluation of insect growth regulators from Azadirachta indica (neem) using rearing tests on honey bee larvae. Mitteilungen der Deutschen Gesellschaft für Allgemeine und Angewandte Entomologie.3:196-198.

Schmutterer, H., and Holst, H. 1987. On the effect of enriched and formulated neem seed kernel extract AZT-VR -K on the honeybee. Zeitschrift fur Angewandte Entomologie. 103(2): 208-213.

Sharma, D., and Abrol, D.P. 2005. Contact toxicity of some insecticides to honeybee Apis mellifera (L.) and
Apiscerana (F.). Journal Asia-Pacific Entomology 8(1): $\quad$ 113-115.

Sinha, P.B., Singh, D.S., Naim, $M$ and Srivastava, B.G. 1997. Contact toxicity of some insecticides to oriental honeybee, Apis cerana indiaca foragers. Annals of Plant Protection Sciences 5(2): 207-209.

Sokal, R.R., and Rholf, F.J. 1981. Biometry. 2nd Edition. W.H. Freeman \& Co., San Francisco

Sundararaju, D. 2003. Occurrence of bee fauna and extent of pollination in insecticide sprayed ecosystem of cashew. Journal of Palynology. 39: 121-125.

Wael-L-de and Laere-O-van. 1989. Toxicity and the repellent activity of synthetic pyrethroids towards the honey bee (Apis mellifera L.). Proceedings of the $31^{\text {st }}$ International Congress of Apiculture held on 19-25 Aug., 1987 at Warsaw, Poland. 209-216.

\section{How to cite this article:}

Ratnakar, V., S.R. Koteswara Rao, D. Sridevi and Vidyasagar, B. 2017. Contact Toxicity of Certain Conventional Insecticides to European Honeybee, Apis mellifera Linnaeus. Int.J.Curr.Microbiol.App.Sci. 6(8): 3359-3365. doi: https://doi.org/10.20546/ijcmas.2017.608.401 